Egyptian Journal of Aquatic Biology \& Fisheries

Zoology Department, Faculty of Science,

Ain Shams University, Cairo, Egypt.

ISSN 1110 - 6131 Vol. 22(2): 119- 136 (2018)

ejabf.journals.ekb.eg

\title{
State of Seasonal Environmental Factors of the Hadhramout Coast, Gulf of Aden, Yemen
}

\section{Ali Attaala Mukhaysin ${ }^{1}$; Shavel Inna I. $^{2}$; Bazar Salem R. ${ }^{1}$; Kurochkina Tatyana . $^{3}$ and Nasibulina Bogatoz M. ${ }^{3}$}

1- Faculty of Environmental Sciences and marine Biology, Hadhramout University, Mukalla, Yemen

2- Faculty of chemistry, Astrakhan State Technical University, Astrakhan, Russia

3- Faculty of Geology \& Geography/ Innovative Natural Institute, Astrakhan State University, Astrakhan, Russia

*Corresponding Author, atta_mh@yahoo.com

\section{ARTICLE INFO \\ Article History: \\ Received: May 20, 218 \\ Accepted: June 21, 2018 \\ Available online:July 2018}

\section{Keywords:}

Hadhramout Coast

Gulf of Aden

Yemen

Environmental parameters nutrients

Monsoon

\section{ABSTRACT}

The present study was conducted during the period from September 2009 to February 2011 to assess temporal and spatial changes in physicochemical and biological parameters of Hadhramout coast. The investigation was carried out at 5 coastal stations; selected to represent the habitats of the Hadhramout Coast, at a distance of about 1.5 kilometers away from the beach. The results showed that the monthly and locality changes in the parameters were, to some extent, heterogeneous. They were varied as follows: water temperature ranged, as monthly average, from 25 ${ }^{\circ} \mathrm{C}$ in Mukalla station in February to $31^{\circ} \mathrm{C}$ in Bir Ali in June (annual mean). In general, the means of salinity were more stable, less heterogeneous. Mean of surface salinity of the coast in this study was ranging between $(34.3 \mathrm{~g} / \mathrm{L})$ during the south-west monsoon to $(36.4 \mathrm{mg} / \mathrm{L})$ in the pre-winter monsoon (in the area of Bir Ali). Although a relative heterogeneity in the $\mathrm{pH}$ value among the stations, there is a general tendency to decrease during the months of the year towards the Southwestern Monsoon, especially in the area of Bir Ali and Broome. Mean of dissolved oxygen value (DO) in the surface water was $4.86 \pm 0.08$ mg / L after the summer Monsoon (October of Bir Ali station) to $6.8+$ $0.21 \mathrm{Mg} / \mathrm{l}$ in winter monsoon (February of Shehir station). The concentration of nutrients can clearly describe the Hadhramout Coast as a high biologically rich water body over most months of the year. Changes of these parameters were discussed in details Turbidity in the coast was characterized by low values and an important spatio-temporal variability. The results point out that this coast contains more dissolved oxygen, more nutrients and fishes.

\section{INTRODUCTION}

Since the middle of the $20^{\text {th }}$ century, the Gulf of Aden has been regarded as one of the world's most distinguished natural and ecological water basin (Baars et al., 1998) exposed to many distinct geographic aspects - topographic, climatic and energetic. The main aspect is distinguished by its unique depth and topography - the average depth is $1750 \mathrm{~m}$, the middle of the Gulf the depth reach up to 5370 meters with severe terrain bottom, making it the third location among the global ocean bays. 
The climate phenomenon and its effects on this Gulf are the influence of the southwestern wind, summer monsoon, and the movement of water masses - the Upwelling, the northeastern wind and the relatively quiet and dry winter monsoon in the north part of the Gulf. Other phenomenon is the biological, which characterizes the richness of this qualitative and quantitative Gulf with phytoplankton and its subsequent zooplankton, mollusks, crustaceans and fish (Dubinets, 1989; Wiebinga et al., 1997).

Some of the richness of the Gulf of Aden is also manifested by the presence of coral complexity, which are distributed as isolated and patchy aggregations, usually occupies rocky bottoms in the region of BirAli and Balhaf coasts, dominated by aggregates: Pocilloporids, Favids and Poritids (Kemp and Benzoni, 2000).

The east of the Gulf of Aden includes the coast of Hadhramout is one of the most productive of the global ocean and has an average productivity of more than 100 miles from the coast, which exceeds the productivity of the other Upwelling regions such as the coast of Peru and West Africa (Krey and Babenard, 1976). The highest productivity of this area (more than $1000 \mathrm{mg} / \mathrm{m}$ ) was observed in August at the end of the South West monsoon and the lowest yield (about $400 \mathrm{mg} / \mathrm{m}$ ) in January during the North East monsoon (Nair, 1980; Madhupratap et al., 1981).

The coast of Hadhramout is characterized by its own location, in addition to its exposure to the mentioned phenomena, which makes it eutrophic among the western Arabian sea, which is generally characterized by oligotrophic-poor in nutrients and plant life and rich in oxygen, and the center of the Gulf of Aden, characterized by the phenomenon of Upwelling and eutrophic, which is rich in nutrients and micro-life (Piontkovski and Claereboudt, 2012).

In this regard, the region is characterized by a wide variety of fish including sardines, anchovies, representatives of Serranidae, Lethrinidae and other commercial fish families. Indian oil sardines (Sardinella longiceps) and the Indian mackerel (Rastrelliger kanagurta) are abundant and support the coastal catch of the Gulf of Aden by surface fish of more than 30,000 tons annually (IFAD, 2010).

Studies in the characteristics of marine conditions are important in fisheries research, because conditions at sea play a major role in fish availability and coexistence. Variations in physical, chemical and biological conditions have a profound impact on the periodicity and seasonality of fish migration in the sea. Environmental, oceanic and marine climatic systems usually lead to fluctuations in abundance of exploited fish populations (Kawasaki et al., 1991; Francis and Hare, 1994).

\section{MATERIALS AND METHODS}

\section{Description of the region, and stations:}

Hadhramout coast as coastline of Hadhramout province constitute nearly 14\% of the Yemeni total coast and more than $20 \%$ of the North Gulf of Aden coast. It consists of a series of sandy beaches interspersed with periods of the protruding rock formations, often extends into the shallow water, especially in its western part Broom and BirAli. Slope of sea bottom here is steep, where the distance between the beach and continental shelf relatively narrow - an average of $15 \mathrm{~km}$, except in the southeast of the country where it can reach $60 \mathrm{~km}$ in width. Depths of the Gulf in the corresponding part of the coast of Hadhramout are characterized by a considerable disparity as a result of a series of mountainous ridges and crossing trenches lies from the northeast towards the southwest. 
There are some sandy beaches, consisting of rocky highlands backgrounds, such as rocky shores of the east of Bir Ali, Mayfa'a Hager, east of Mukalla and Sharma. There are many areas of environmental importance along the coast, from which the coast with high bio-energy of Beer Ali and its islands and coral formations. This, in addition to the distinct transitional coast of Broome from moderate bioenergy of the cape of Ras-El Kalb to the high energy stretching along the Eastern Broom, Halla and Khalaf Al-Mukalla.

The water column in the coast of Hadhramout characterized by a good mix of the surface layers, which separated from the under surface water layers by a very stable layers at a depth of about 100 meters (Badhafari, 2003).

\section{Sampling and analysis methods:}

The station locations were fixed with the help of a Global Positioning System (GPS), on a transect parallel to the shoreline and at $1500 \mathrm{~m}$ from it. Study Station Locations are: Bir Ali: $13^{0} 55^{\prime} \mathrm{N} 48^{0} 26^{\prime} \mathrm{E}$; Broom: $14^{0} 22^{\prime} \mathrm{N} 49^{0} 00^{\prime} \mathrm{E}$; Khalf Mukalla: $14^{0} 29^{\prime}$ N $49^{0} 14^{\prime}$ E; Al-Shiher: $14^{0} 43^{\prime}$ N $49^{0} 40^{\prime}$ E; Sharma: $14^{0} 48^{\prime}$ N $50^{0} 00^{\prime}$ E (Fig. 1).

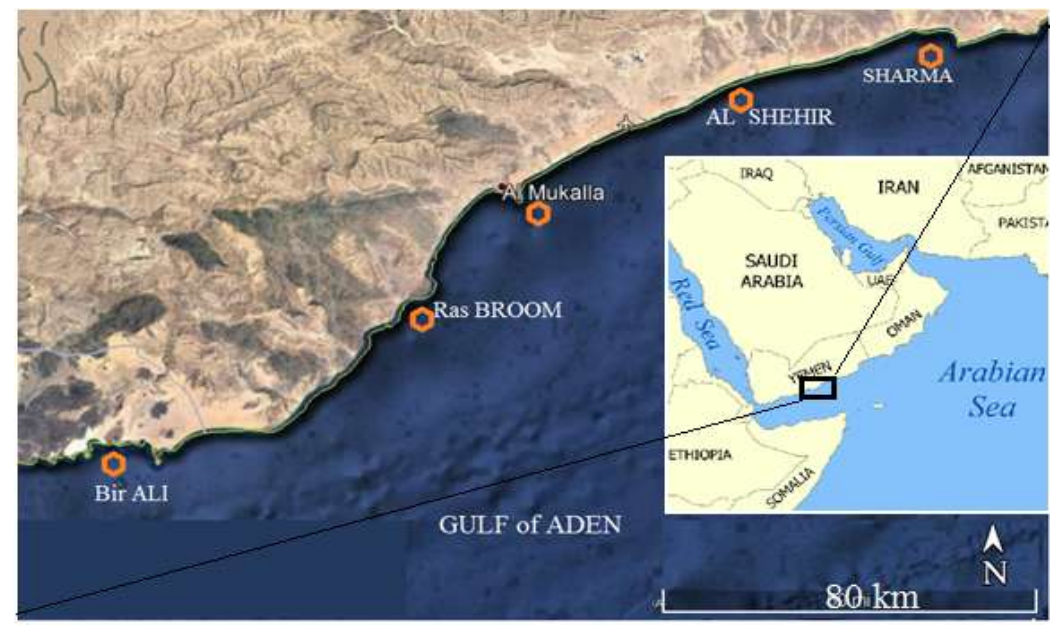

Fig. 1: Hadhramout Coast showing the location of collected stations

All environmental parameters (temperature, salinity, dissolved oxygen, nutrients; phosphorus, nitrate and silicate, and chlorophyll a) were measured using the analytic - optical electronic equipment and devices- a Multiple Water Analysis Probe Model YSI 6600-V2 zoned, directly at the station - in situ. For calibration and insurance; the analysis was done by field-testing apparatus, such as a traditional Oxygen meter, (type: Oxi -3310 WTW 2BA301, Germany), salinity by (Inolab Cond 720 from WTW, Germany), the turbidity by turbidimeter after direct calibration with constant references - 0.02, 10, 1000 (WTW TURB 355T NTU)).

Our focus was on the surface layer of the water and to a depth of 10 meters for the analysis of physical and chemical parameters. Additional water samples for the determination of the physical and chemical variables were collected in pre-cleaned polythene bottles from the five sites of each sampling station monthly (pre-monsoon: February to May, Monsoon: June to September and post-monsoon: October to January; in which the seasons of summer and winter Monsoons were covered. For example, November 2010 represents the period between summer and winter monsoons, January 2011 represents winter monsoon, May 2011 represents the period between winter and summer monsoons and August 2011 represents the apex of summer monsoon). Generally, coastal surveys were conducted during the period from 
September 2009 to February 2011 inclusively. However, we've mostly focused on the 2010 parameters for comparison and analysis.

Subsurface water samples were collected by a 5 -litre Niskin bottle for analysis of nutrients. Nutrient samples were frozen at $-20^{\circ} \mathrm{C}$ and analyzed using a 5-channels SKALAR Flow Access nutrient auto-analyzer according to the procedure described in Strickland and Parsons (1972), and modified by the manufacturer (Skalar analytical, 1996).

\section{RESULTS AND DISCUSSION}

\section{Environmental conditions: \\ Temperature}

Generally the surface temperature of the water of Hadhramout Coast during the study period had ranged, as monthly average, from $25^{\circ} \mathrm{C} \pm 0.08$ in Mukalla station in February to $31^{\circ} \mathrm{C} \pm 0.24$ in Bir Ali in June (annual mean for the coast $-27.445^{\circ} \mathrm{C}$ \pm 0.2 ) (Fig. 1). At the bottom $\left(75-100 \mathrm{~m}\right.$ ) it had ranged between $15.4^{\circ} \mathrm{C} \pm 0.11$ in $\mathrm{Bir}$ Ali station in October and $24.5^{\circ} \mathrm{C} \pm 0.31$ in the station of Shehir in February (the annual mean of the coast $-20.06{ }^{\circ} \mathrm{C} \pm 0.17$ ).

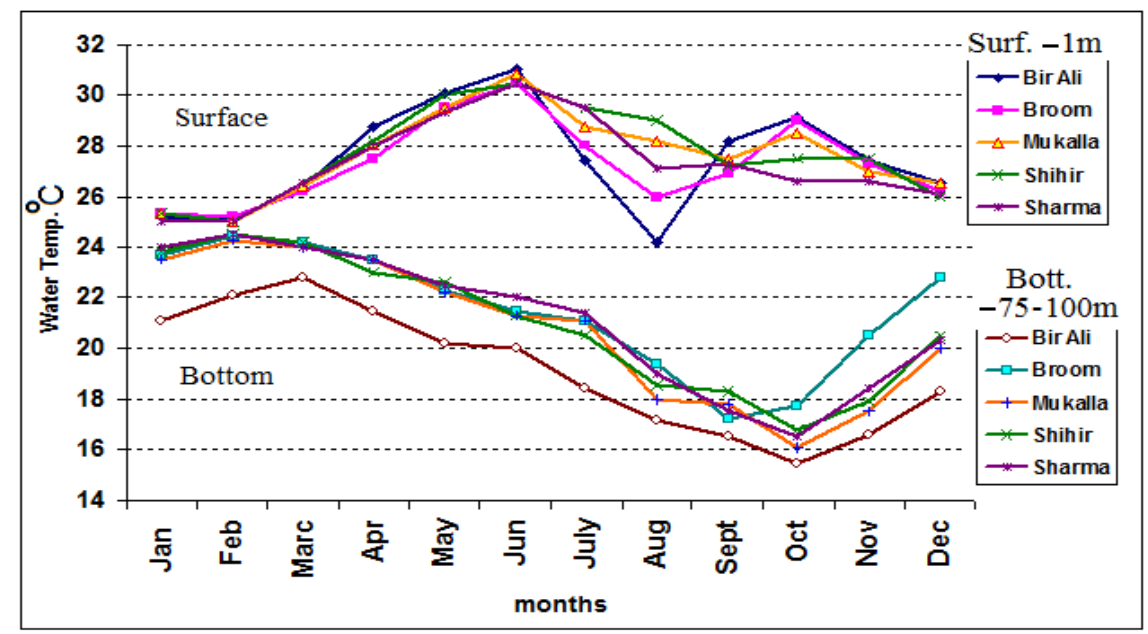

Fig. 2: The temperature of the water mass of the Hadhramout coast during 2010 in different seasons and stations

Water temperature has shown a spatial and temporal variations due to the vertical stratification caused by the movement of water masses and regional currents, which are governed by the intensity or strength of different seasonal monsoons. Surface water temperature in winter monsoon (February) was $\left(25 \pm 0.2^{\circ} \mathrm{C}\right)$, in either summer monsoon (July-August) it varied between $42.2 \pm 0.05{ }^{\circ} \mathrm{C}$ and $29.5 \pm 0.11^{\circ} \mathrm{C}$. The temperature of bottom layered remains almost equal to the surface; one before southwest monsoon - about $25^{\circ} \mathrm{C}$ (February) and less by about $7-8{ }^{\circ} \mathrm{C}$ on an average of the summit of summer monsoon- July and August (the amount of alternating here within the different regions and months between 6.5 and 14.5 degrees ${ }^{\circ} \mathrm{C}$ ) (Table 1). 
Table 1: The variation in the temperature $\left(C^{\circ}\right)$ of the Hadhramout Coast during 2010

\begin{tabular}{|l|c|c|c|c|c|c|c|c|c|c|}
\hline \multicolumn{9}{|c|}{ Surface } & \multicolumn{5}{c|}{ bottom 75m } \\
\hline Month & Bir Ali & Broom & Mukalla & Shihir & Sharma & Bir Ali & Broom & Mukalla & Shihir & Sharma \\
\hline Jan & 25.2 & 25.3 & 25.3 & 25.3 & 25.0 & 21.1 & 23.7 & 23.5 & 23.8 & $\mathbf{2 4 . 0}$ \\
\hline Feb & 25.1 & 25.2 & 25.0 & 25.0 & 25.0 & 22.1 & 24.4 & 24.3 & 24.5 & $\mathbf{2 4 . 5}$ \\
\hline Marc & 26.3 & 26.2 & 26.4 & 26.5 & 26.5 & 22.8 & 24.2 & 24.0 & 24.2 & $\mathbf{2 4 . 0}$ \\
\hline Apr & 28.8 & 27.5 & 28.0 & 28.2 & 28.0 & 21.5 & 23.5 & 23.5 & 23.0 & $\mathbf{2 3 . 5}$ \\
\hline May & 30.1 & 29.5 & 29.5 & 30.0 & 29.3 & 20.2 & 22.3 & 22.2 & 22.6 & $\mathbf{2 2 . 5}$ \\
\hline Jun & 31.0 & 30.5 & 30.8 & 30.5 & 30.5 & 20.0 & 21.5 & 21.3 & 21.3 & $\mathbf{2 2 . 0}$ \\
\hline July & 27.4 & 28.0 & 28.8 & 29.5 & 29.5 & 18.4 & 21.1 & 21.1 & 20.5 & $\mathbf{2 1 . 4}$ \\
\hline Aug & 24.2 & 26.0 & 28.2 & 29.0 & 27.1 & 17.1 & 19.4 & 18.0 & 18.5 & $\mathbf{1 9 . 0}$ \\
\hline Sept & 28.2 & 26.9 & 27.5 & 27.2 & 27.3 & 16.5 & 17.2 & 17.8 & 18.3 & $\mathbf{1 7 . 5}$ \\
\hline Oct & 29.1 & 29.0 & 28.5 & 27.5 & 26.6 & 15.4 & 17.8 & 16.1 & 16.8 & $\mathbf{1 6 . 5}$ \\
\hline Nov & 27.4 & 27.3 & 27.0 & 27.5 & 26.6 & 16.6 & 20.5 & 17.5 & 17.9 & $\mathbf{1 8 . 4}$ \\
\hline Dec & 26.5 & 26.2 & 26.5 & 26.0 & 26.1 & 18.3 & 22.8 & 20.0 & 20.5 & $\mathbf{2 0 . 3}$ \\
\hline
\end{tabular}

As appears from the above results, the warming system of surface waters of the Hadhramout coast followed an apparent annual cycle of moderate recorded low temperatures in winter and highest in the summer months. Relative decline has been observed in most coastal stations during July and August due to the rise of the cold bottom waters under the influence of coastal winds, which create summer monsoonal upwelling and moderate cyclonic eddies. Such changes often occur in many of the coasts (Coles and Seapy, 1998; Mann and Lazier, 2006), which cause most of the usual chemical and biological changes in coastal ecosystems (Agawin et al. 2000; AlHashmi et al. 2010).

\section{Salinity:}

The salinity fluctuated during the study period over the coast between 34.3 and 36.4 grams per liter, which recorded in October and July, respectively (Table 2). In general, the means of salinity were more stable, less heterogeneous, despite that the coast is located under the influence of multiple sources of water bodies, which shapes the waters of the Gulf. These sources are RSW (Red Sea waters) with high salinity $(40 \mathrm{~g} / \mathrm{L})$ but it below the limits of the studied depths more than 100 meters; the relatively low salinity (35g/L), ASW (waters of the Arabian Sea) which occupy subsurface waters of the Gulf, and gulf self-forming layer studied here.

Table 2: The variation in salinity index ( $\mathrm{S} \%$ ) of the Hadhramout coast by months

\begin{tabular}{|c|c|c|c|c|c|c|c|c|c|c|}
\hline \multicolumn{6}{|l|}{ Surface } & \multicolumn{5}{|c|}{ bottom $75 \mathrm{~m}$} \\
\hline Month & Bir Al & Broom & Mukalla & Shehir & Sharma & Bir Ali & Broom & Mukalla & Shihi & Sharma \\
\hline Oct 09 & 36.3 & 36.0 & 35.8 & 35.5 & 36.0 & 35.6 & 35.9 & 35.9 & 35.7 & 35.5 \\
\hline Nov & 35.9 & 35.7 & 35.6 & 35.3 & 36.0 & 35.6 & 35.6 & 35.6 & 35.5 & 35.6 \\
\hline Dec & 36.2 & 35.7 & 35.7 & 35.7 & 35.9 & 35.6 & 35.8 & 35.8 & 35.5 & 35.6 \\
\hline Jan 10 & 35.9 & 35.7 & 36.0 & 35.5 & 36.0 & 35.9 & 35.8 & 36.1 & 35.4 & 35.9 \\
\hline Feb & 36.2 & 36.2 & 36.2 & 35.0 & 36.1 & 36.1 & 36.2 & 36.2 & 35.0 & 36.0 \\
\hline Mar & 35.4 & 34.7 & 34.7 & 35.3 & 36.1 & 35.8 & 34.4 & 34.4 & 34.3 & 36.0 \\
\hline Apr & 36.2 & 36.0 & 35.0 & 34.3 & 36.2 & 36.1 & 35.8 & 35.3 & 34.3 & 35.6 \\
\hline May & 36.3 & 36.1 & 35.1 & 35.2 & 36.1 & 35.9 & 36.0 & 35.9 & 35.0 & 35.2 \\
\hline Jun & 36.3 & 36.0 & 35.8 & 34.6 & 36.2 & 35.8 & 36.1 & 35.6 & 34.8 & 35.8 \\
\hline July & 36.4 & 35.1 & 35.1 & 34.8 & 35.5 & 35.7 & 35.0 & 35.0 & 34.8 & 35.7 \\
\hline Aug & 35.5 & 34.5 & 34.5 & 34.5 & 34.7 & 35.2 & 34.5 & 34.5 & 34.4 & 35.0 \\
\hline Sep & 34.7 & 36.3 & 34.9 & 35.1 & 34.8 & 34.8 & 36.0 & 35.2 & 35.9 & 35.5 \\
\hline Oct & 35.6 & 36.2 & 35.0 & 35.8 & 35.9 & 35.9 & 35.7 & 35.8 & 35.6 & 36.0 \\
\hline Nov & 36.2 & 35.9 & 36.0 & 35.1 & 36.0 & 36.0 & 35.6 & 36.0 & 34.5 & 36.2 \\
\hline Dec & 35.8 & 35.7 & 35.8 & 34.5 & 35.7 & 36.0 & 35.9 & 35.8 & 36.3 & 35.7 \\
\hline Jan 11 & 35.8 & 36.0 & 36.2 & 36.0 & 36.0 & 36.5 & 35.8 & 35.7 & 36.4 & 36.3 \\
\hline
\end{tabular}


Mean of surface water salinity of the coast in this study is ranged between $(34.3 \mathrm{~g} / \mathrm{L})$ during the south-west monsoon to $(36.4 \mathrm{mg} / \mathrm{L})$ in the pre-winter monsoon (in the area of Bir Ali). After the summer monsoon (November), the salinity moderated to stabilize over the next three months around the average of 35.4, with convergent indicators of each of the surface and bottom waters (Table 2, Fig. 3).

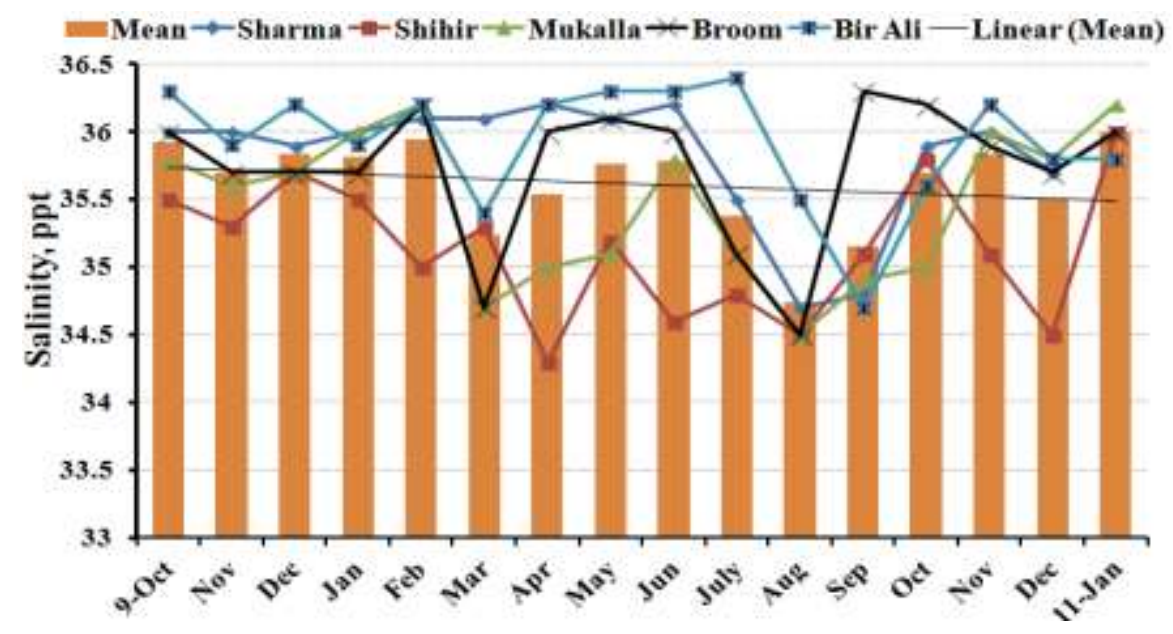

Fig. 3: The variability of salinity (ppt) of the Hadhramout water mass

Seasonal changes of the salinity usually is influenced and determined by evaporation level and interaction of moving water bodies. They often are similar to vertical water temperature variance; but what was found in the eastern Gulf of Aden (Khimitsa, 1970) and the coast of Hadhramout (current study) somewhat differs from this phenomenon, as to overlap the privacy of the different sources of waters of the Gulf and effect of regional and seasonal upwelling.

pH:

$\mathrm{pH}$ is other environmental factor that affect the growth, survival and productivity of marine organisms. $\mathrm{pH}$ from its side affected through photosynthesis and respiration of plants and animals and by human-made wastes. However it is one of the stable measurements in seawater (Pearson and Palmer, 2000).

Transect along the Hadhramout coast water column revealed a limited $\mathrm{pH}$ spatial heterogeneity (from approximately 7.85 up to 8.35-0.5 units). $\mathrm{pH}$ levels were lower along the bottom than in the surface coast, especially at Bir Ali and Broom toward end of the SWM in August - Dec (Table 4, Fig.4 ).

As noted, the convergence of the index for all stations was in the months of June (difference- 0.25 units) and September (difference- 0.23 units), almost coinciding with beginning and end of the phenomenon Upwelling in the coast-Southern West Monsoon (Fig. 4), which confirms the well mixing of the water mass of the coast. The largest difference was noted in Northern Winter Monsoon-January (0.45 units). The close proximity was between the stations of Bir Ali and Broome that observed during the months of the Southern West Monsoon and can be explained by their intense influencing by this phenomenon (Ali and Bazar, 2016).

Although we note a relative heterogeneity in the $\mathrm{pH}$ index between the stations (variation up to 0.5 units), there is a general tendency to decrease during the months of the year towards the Southwestern Monsoon and beyond in the surface water, especially in the area of Bir Ali and Broome; while this drop does not noticed in bottom waters (Fig. 4). 
Table 4: Monthly variations of $\mathrm{pH}$ in the surface and bottom water stations in Hadhramout coast

\begin{tabular}{|c|r|r|r|r|r|c|c|c|c|c|c|c|}
\hline \multicolumn{1}{|c|}{$\begin{array}{c}\text { Mont } \\
\text { hs }\end{array}$} & $\begin{array}{c}\text { Bir } \\
\text { Ali }\end{array}$ & $\begin{array}{c}\text { Broo } \\
\text { m }\end{array}$ & $\begin{array}{c}\text { Muk } \\
\text { all }\end{array}$ & $\begin{array}{c}\text { She } \\
\text { hir }\end{array}$ & $\begin{array}{c}\text { Shar } \\
\text { ma }\end{array}$ & $\begin{array}{c}\text { Me } \\
\text { an }\end{array}$ & $\begin{array}{c}\text { Bir } \\
\text { Ali }\end{array}$ & $\begin{array}{c}\text { Broo } \\
\text { m }\end{array}$ & $\begin{array}{c}\text { Muka } \\
\text { lla }\end{array}$ & $\begin{array}{c}\text { She } \\
\text { hir }\end{array}$ & $\begin{array}{c}\text { Shar } \\
\text { ma }\end{array}$ & $\begin{array}{c}\text { Me } \\
\text { an }\end{array}$ \\
\hline Jan & 8.28 & 8 & 8.18 & 8.2 & 7.85 & 8.17 & 7.91 & 7.87 & 7.86 & 8.1 & 7.7 & 7.99 \\
\hline Feb & 8.28 & 8.3 & 8.22 & 8.2 & 7.92 & 8.05 & 7.85 & 7.79 & 8.33 & 8 & 7.8 & 7.98 \\
\hline Mar & 8.16 & 8.2 & 8.27 & 8.15 & 7.9 & 8.12 & 8.35 & 8.44 & 8.11 & 8.4 & 7.7 & 8.12 \\
\hline Apr & 8.1 & 8 & 8.35 & 8.4 & 8.1 & 8.17 & 7.97 & 7.76 & 8.31 & 8.1 & 7.7 & 8.15 \\
\hline May & 8.1 & 8.2 & 8.23 & 7.95 & 7.88 & 8.08 & 7.89 & 7.7 & 8.13 & 7.9 & 7.7 & 7.94 \\
\hline Jun & 8.07 & 8 & 8.15 & 8 & 7.9 & 8.01 & 8.13 & 8.1 & 8.2 & 7.7 & 7.7 & 8.01 \\
\hline July & 8 & 8.13 & 8.3 & 7.88 & 8.2 & 8.10 & 7.96 & 8 & 8.18 & 7.9 & 8 & 8.13 \\
\hline Aug & 8 & 8 & 8.22 & 7.9 & 8.1 & 8.18 & 8 & 8.3 & 8.35 & 7.9 & 8.2 & 8.18 \\
\hline Sept & 7.98 & 8.03 & 8.16 & 8.21 & 8.2 & 8.21 & 8.3 & 7.8 & 8.25 & 7.9 & 8 & 8.21 \\
\hline Oct & 7.97 & 8.14 & 8.07 & 7.9 & 8.2 & 8.11 & 8.1 & 7.7 & 8.32 & 7.7 & 8.2 & 8.19 \\
\hline Nov & 7.96 & 8.1 & 8.22 & 7.85 & 8 & 8.09 & 7.8 & 7.68 & 8.45 & 7.5 & 8 & 8.07 \\
\hline Dec & 7.89 & 7.9 & 7.96 & 8.2 & 8 & 7.99 & 7.8 & 7.9 & 7.96 & 7.9 & 7.8 & 7.85 \\
\hline
\end{tabular}

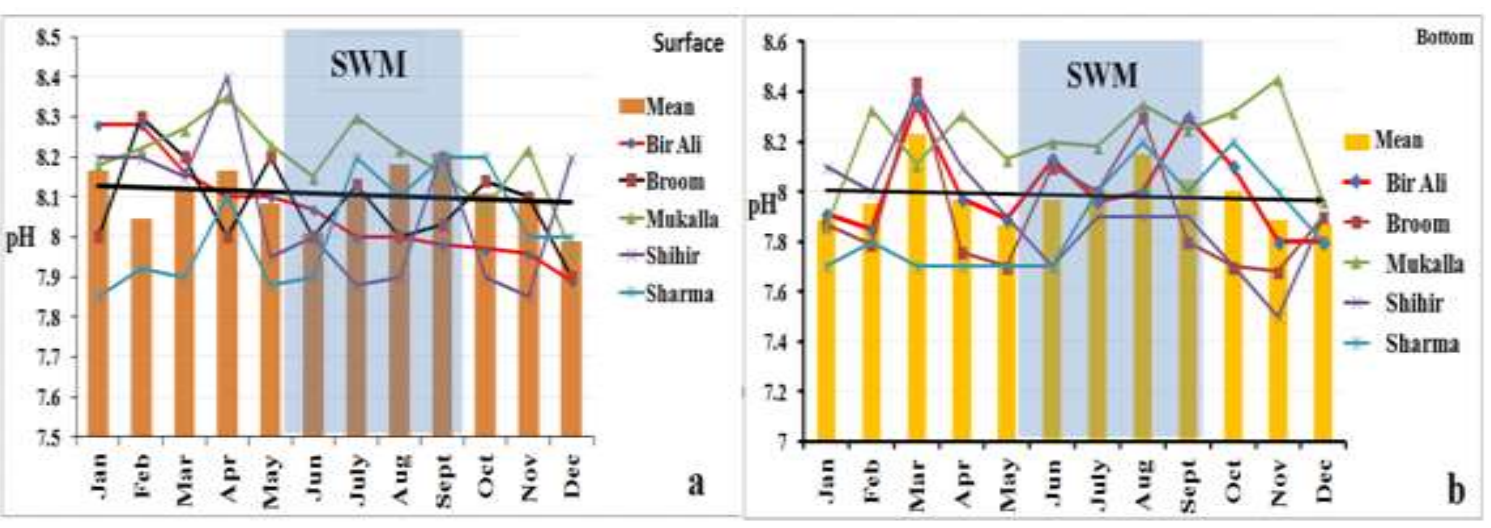

Figure 4:The variability of $\mathrm{pH}$ value of the Hadhramout water

Along the coast the bottom water $\mathrm{pH}$ ranged between 8.45 and 7.5. The lowest $\mathrm{pH}$ (7.5) was detected in the bottom waters of Shehir in Nov. and Sharma throughout the first half of the year (Fig. 4). The highest bottom pH was in Mukalla in Nov.

As we can see there was no significant correlation $(r=0.138)$ between the $\mathrm{pH}$ means and the abundance of phytoplankton as chlorophyll $\mathbf{a}$ in Hadhramout coast (Ali and Bazaar, 2006); no statistically significant association was detected between them.

Unlike our results the pattern of north-south decline in $\mathrm{pH}$ value was observed in western Bay of Bengal coast (Sarma et al., 2015). It seems that the heterogeneity of $\mathrm{pH}$ parameter of the coast of Hadhramout not much different from South east coast of India, where slightly alkaline range in $\mathrm{pH}$ was reported 7.7-8.3 (Satpathy et al. 2009). Omstedt et al. (2010) reported that the marginal change in $\mathrm{pH}$ from one month to another may be due to the excessive buffering activity of sea water, which was mostly observed in monsoon season.

The impact of the $\mathrm{pH}$ parameter on the chlorophyll index in the Hadhramout coast indicates that $\mathrm{pH}$ is an insignificant factor in the dynamics of phytoplankton in coastal environments.Thus, the $\mathrm{pH}$ levels recorded in water of Hadhramout coast were ranged vetween 7.85 to 8.35 with a mean of 8.2 (Table 4 and Fig. 4 ) is generally conducive to aquatic life (Wang et al., 2004).Thus, it can be stated that the $\mathrm{pH}$ in the coast of Hadhramout is subject to low changes at various spatial and temporal scales. At the same time, a significant (by more than 0.2 ) decrease in the $\mathrm{pH}$ value in the 
surface layer was caused, mainly due to the cyclonic enhancement and upwelling gain in the western parts of the Hadhramout coast.

Unfortunately no past data exist, to assess the long-term dynamics of $\mathrm{pH}$ of Hadhramout coast that have the greatest probability of a leisurely acidification from anthropogenic $\mathrm{CO}_{2}$ emissions. Our study provides, to our knowledge, the first record and reconstruction of seasonal cycle of $\mathrm{pH}$ in Gulf of Aden coasts.

\section{Dissolved oxygen:}

It is well known that dissolved oxygen in water is very important for the life of aquatic organisms where it is used for breathing in addition to the need for it in all biological and physico-chemical activities. The amount of oxygen dissolved in water usually varies according to the type and effectiveness of life in the water mass. Renewal of dissolved oxygen is usually generated by the effectiveness of photosynthesis of aquatic plants, in particular living phytoplankton, and by dissolving atmospheric oxygen in the surface of the water due to the nature of the latter movement and wave intensity that are directly proportional to the intensity of wind and currents caused by Seasonal weather conditions - monsoons (Beal and Chereskin, 2003).

As for the Hadhramout coast, the result of analysis of water masses of the surface layers showed that the mean of dissolved oxygen index (DO) in the surface water was $4.86 \pm 0.08 \mathrm{mg} / \mathrm{L}$ after the summer Manson (October of Bir Ali station) to $6.8+0.21 \mathrm{Mg} / 1$ in winter monsoon (February of Shehir station). The low variation between stations and months was noticed, except for the relative differences between the pre-and post-winter seasons (Fig. 5). As for the dissolved oxygen at the bottom, as shown in the figure, the picture changes clearly as this indicator are affected frequently by seasons. The dissolved oxygen value increases during the winter (January, March), which coincides with winter monsoon, and gradually decreases towards the end of the summer monsoon. The lowest bottom indicators (1.38 and 1.64) were recorded in September and October as showing in Figure (5) and Table (5). It is noticed that the amount of oxygen dissolved in water is a general upward trend from the west coast in Bir Ali, to its east on the Arabian Sea in Shehir and Sharma region.

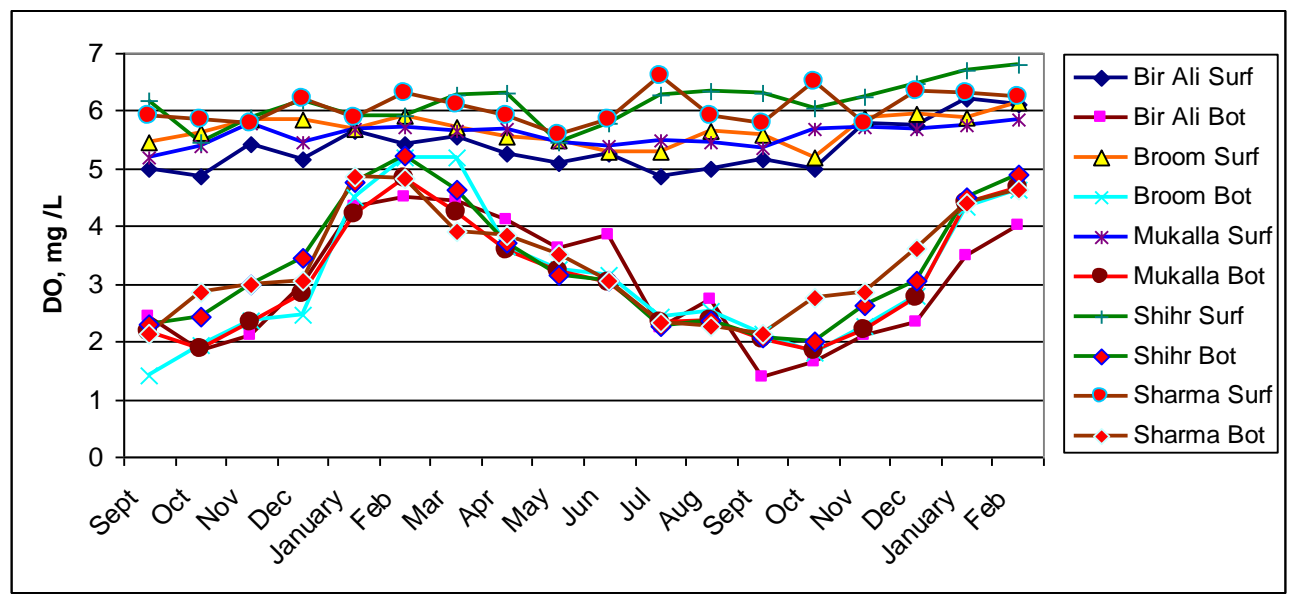

Fig. 5: Dissolved oxygen (mg / l) in the Hadhramout coast during the period (Sep. 2009, 2010 to Feb. 2011). 
Table 5: Dissolved oxygen (mg / L) in the areas of Hadhramout coast during the period (Sep. 2009, 2010 to Feb. 2011)

\begin{tabular}{|l|l|l|l|l|l|l|l|l|l|l|}
\hline Surface \\
\hline Month & Bir Ali & Broom & Mukalla & Shihir & Sharma & Bir Ali & Broom & Mukalla & Shihir & Sharma \\
\hline Sept & 5.00 & 5.46 & 5.20 & 6.17 & 5.90 & 2.44 & 1.42 & 2.17 & 2.30 & 2.12 \\
\hline Oct 09 & 4.86 & 5.62 & 5.40 & 5.44 & 5.85 & 1.83 & 1.95 & 1.88 & 2.44 & 2.85 \\
\hline Nov & 5.43 & 5.86 & 5.80 & 5.87 & 5.80 & 2.10 & 2.37 & 2.32 & 3.00 & 3.00 \\
\hline Dec & 5.17 & 5.86 & 5.47 & 6.17 & 6.20 & 3.00 & 2.48 & 2.83 & 3.45 & 3.05 \\
\hline Jan & 5.65 & 5.69 & 5.70 & 5.93 & 5.88 & 4.35 & 4.49 & 4.21 & 4.75 & 4.86 \\
\hline Feb 10 & 5.43 & 5.93 & 5.73 & 5.90 & 6.30 & 4.50 & 5.20 & 4.82 & 5.23 & 4.82 \\
\hline Mar & 5.56 & 5.71 & 5.65 & 6.27 & 6.10 & 4.44 & 5.20 & 4.24 & 4.62 & 3.90 \\
\hline Apr & 5.26 & 5.57 & 5.67 & 6.30 & 5.90 & 4.10 & 3.66 & 3.58 & 3.70 & 3.85 \\
\hline May & 5.10 & 5.50 & 5.47 & 5.44 & 5.60 & 3.62 & 3.25 & 3.22 & 3.16 & 3.52 \\
\hline Jun & 5.27 & 5.30 & 5.38 & 5.80 & 5.86 & 3.86 & 3.14 & 3.02 & 3.05 & 3.05 \\
\hline Jul & 4.85 & 5.30 & 5.49 & 6.27 & 6.62 & 2.24 & 2.42 & 2.33 & 2.27 & 2.33 \\
\hline Aug & 5.00 & 5.64 & 5.45 & 6.33 & 5.93 & 2.73 & 2.54 & 2.38 & 2.35 & 2.27 \\
\hline Sept & 5.16 & 5.58 & 5.37 & 6.30 & 5.80 & 1.38 & 2.15 & 2.04 & 2.08 & 2.15 \\
\hline Oct & 5.00 & 5.20 & 5.68 & 6.05 & 6.50 & 1.64 & 1.82 & 1.84 & 2.01 & 2.76 \\
\hline Nov & 5.80 & 5.88 & 5.71 & 6.24 & 5.80 & 2.10 & 2.27 & 2.21 & 2.64 & 2.86 \\
\hline Dec & 5.75 & 5.95 & 5.68 & 6.48 & 6.35 & 2.33 & 2.78 & 2.75 & 3.07 & 3.62 \\
\hline Jan 11 & 6.20 & 5.88 & 5.75 & 6.72 & 6.30 & 3.50 & 4.33 & 4.40 & 4.50 & 4.42 \\
\hline Feb & 6.10 & 6.13 & 5.85 & 6.80 & 6.26 & 4.00 & 4.62 & 4.68 & 4.90 & 4.65 \\
\hline
\end{tabular}

The temporal and spatial stability of the dissolved oxygen value on the surface of the coast, despite the heterogeneity of other factors, can be explained by the interaction of relatively low water temperature, the effectiveness of the upwelling, and the growth of phytoplankton, where we note that the dissolved oxygen maintained at the same level as before the southwest monsoon months.

\section{Nutrients:}

Nutrients are the limiting factor in algae growth. Usually nitrogen, phosphorous and silica are in the greatest demand and tend to be rather scarce in the marine surface environment (Sigman and Hain, 2012).

Upwelling, driven by the strong southwestern monsoon winds is one of the main sources of nutrient, this as we mention earlier, is when the surface water is moved and deep water comes to the surface to replace it (Anderson and Prell, 1993). That deep water is full of nutrients that have plenty in the coast. Therefore we have lots of sun and lots of nutrients; therefore, there is lots of productivity and thus fishery production. Thus, lots of nutrients erode off the continents themselves and so water close to shore tends to be high in nutrients.

\section{Nitrate:}

The nitrate concentration shows a clearly nature of variation, characterized by the decreasing index in the water column during the winter and moderate abundance in the surface during the summer; during the year the concentration of nitrate ranged between 0.0 and $6 \mathrm{micro}-\mathrm{ml} / \mathrm{L}$. In the benthic layers the concentration gradually increase over time - from the lowest index in January, reaching its peak in summer monsoon months - July, August and September. With the end of the phenomenon of Upwelling in October, the concentration of nitrates becomes more consistent and spread downwards in the water column in January and February. In the same seasonal variation and nature of spatial the indicators of phosphate and silicate were been with the difference in the values of these indicators. 


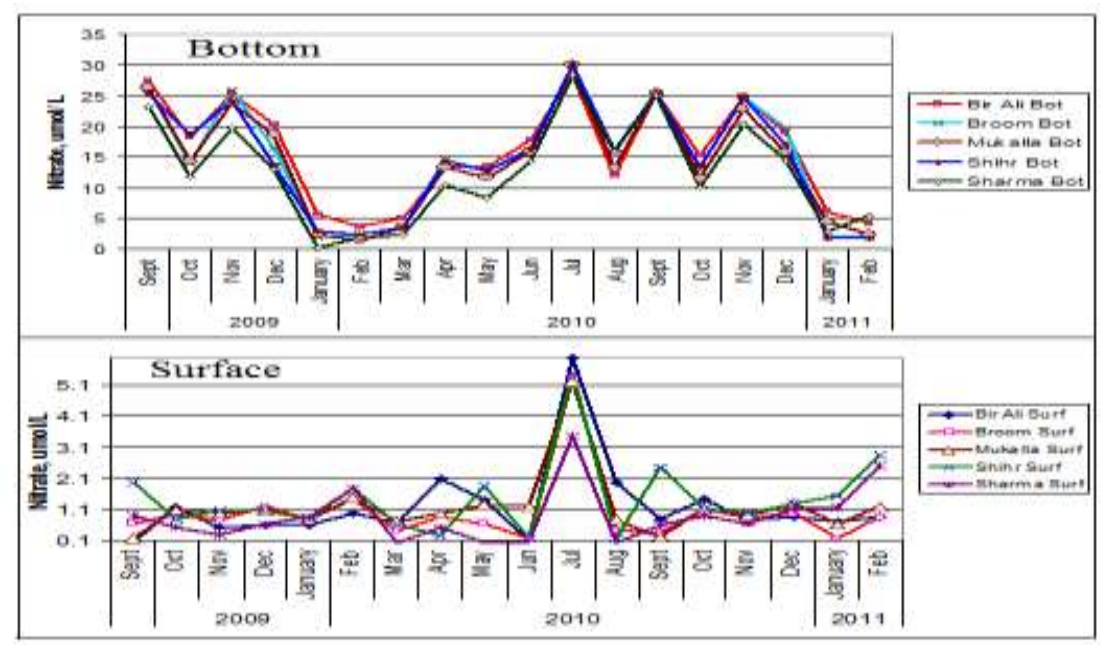

Fig. 6: The variation in the nitrate concentration of the surface and bottom waters of the study areas of the Hadhramout coast.

\section{Phosphate}

The values of phosphate $\left(\mathrm{PO}_{4}\right)$, in the surface and the bottom water of the coast meet in the month of February at 0.5 micromole/ L, to settle around this value at the surface during the year. These values are rising during and after summer monsoonal months at the bottom to reach a maximum in August and September; about 2 micromole/L at all stations, except the marked rise in the relative value of -2.4 at the bottom of the far west coast - Bir Ali.

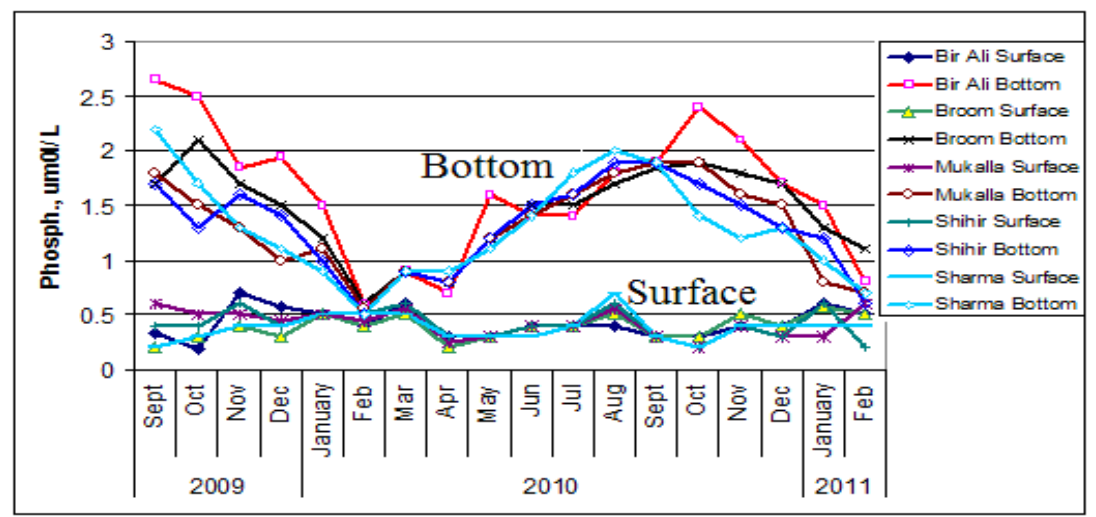

Fig. 7: The concentration of phosphates in the study areas of the coast of Hadramout

\section{Silicate}

The dissolved silicate (DSi) the form of Silicon ( $\mathrm{Si}$ ) is a key nutrient in marine waters; it is taken up by organisms to produce shells and phytoliths (Egge and Aksnes, 1992).

It is similar to phosphate, although the complexities of behavioral interface contrast according to the stations, depths, seasons, and the values difference.

The result of the analysis of this nutrient in the surface water showed that the highest level (more than 28 micrograms/L) had been registered in the region of AlMukalla and Sharma in November, while the lowest level (less than 1) in the same Sharma area in December, where Phytoplankton bloom was at its strong decline. The non-regular pattern of the spatial and seasonal silicate, in and after a peak in the coastal waters, is often due to the consumption of silicate by prevailing diatoms in the composition of the Phytoplankton (Ali and Bazar, 2016). Furthermore, it is because 
of the nature of the seasonal mixing, the predominance and regression of the upwelling, and the physical-chemical conditions of the coast.

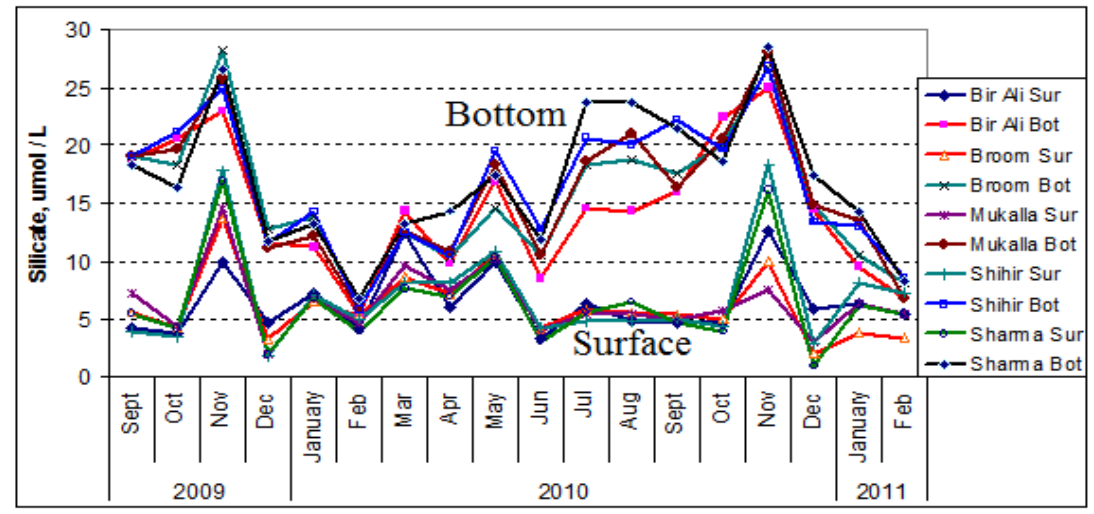

Figure 8: The concentration of silicates in the study areas of the Hadhramout coast

The concentration of nutrients here can clearly describe the Hadhramout coast as a high biologically rich water body over most months of the year. Despite the lack of previous data on the coast and the Gulf of Aden, in general, the comparison with the limited of which shows the compatibility of the studies about high concentrations of these salts in the surface water layers of the Gulf of Aden, as a result of the vertical seasonal movement of currents (upwelling). Latter, were in addition to its abundance, provided by its rapid creating in conditions of relatively high water temperature. Moreover, quantities of some nutrients were increases with a depth to reach its maximum near the bottom (for the silicate); or in surface (for nitrate and phosphate).

If Compared to other parts of the Gulf of Aden, the content of phosphate in the Hadhramout coast is characterized by relative height during the summer months, where its concentration in some stations up to more than 12 micromole/L, compared to the Aden area which had been less than 1, and Ras Fartak - 1.2 micromole /L (Badhafary, 2003).

\section{Turbidity:}

The major source of turbidity in the coastal water is typically phytoplankton, particulates, silts from shoreline erosion, resuspended bottom sediments, and organic detritus. In comparison with the open oceans, the water turbidity in the coastal region is highly dynamic and closely associated with the atmosphere, and ocean variability, such as cyclones (Shi and Wang, 2008) and algae blooms (Wang and Shi, 2008). Suspended sediment particles control the transport, reactivity and biological impacts of substances in the marine environment, and are a crucial link in interactions between the seabed, water column and the food chain (Turner and Millward, 2002).

During our study, the mean values of the Turbidity were ranged between 0.13 and 1.95 NTU. Seasonal values showed that the higher turbidity were through August and September (Fig. 9). Turbidity in the coast was characterized by low turbidity values and an important spatio-temporal variability. Fig. 9 shows a thematic pattern diagram of the integrated absolute indicator of Hadhramout coast turbidity, the distribution of which reflects the location of the region of increased concentration of suspended organic matter.Generally the total surface turbidity in the Hadhramout coast was between 0.1 and 4.02 NTU with a mean for the study period and the entire coast was 1.56 .

The temporal variation of the turbidity values was varied significantly between very low $(0.4 \pm 0.07)$, which was recorded through North East Monsoon in the both 
regions of BirAli and Broome in January and February; and the highest during the months of Upwelling - the monsoon peak which reached $2.84 \pm 0.47$ NTU; distinguishing in the region of BirAli, where the highest turbidity was recorded during the study in September that was 4.02. From a spatial point of view, the central and westward areas (Mukalla - BirAli) show the largest increases to be compared to eastward of the coast, especially areas BirAli and Broom (Fig. 9).

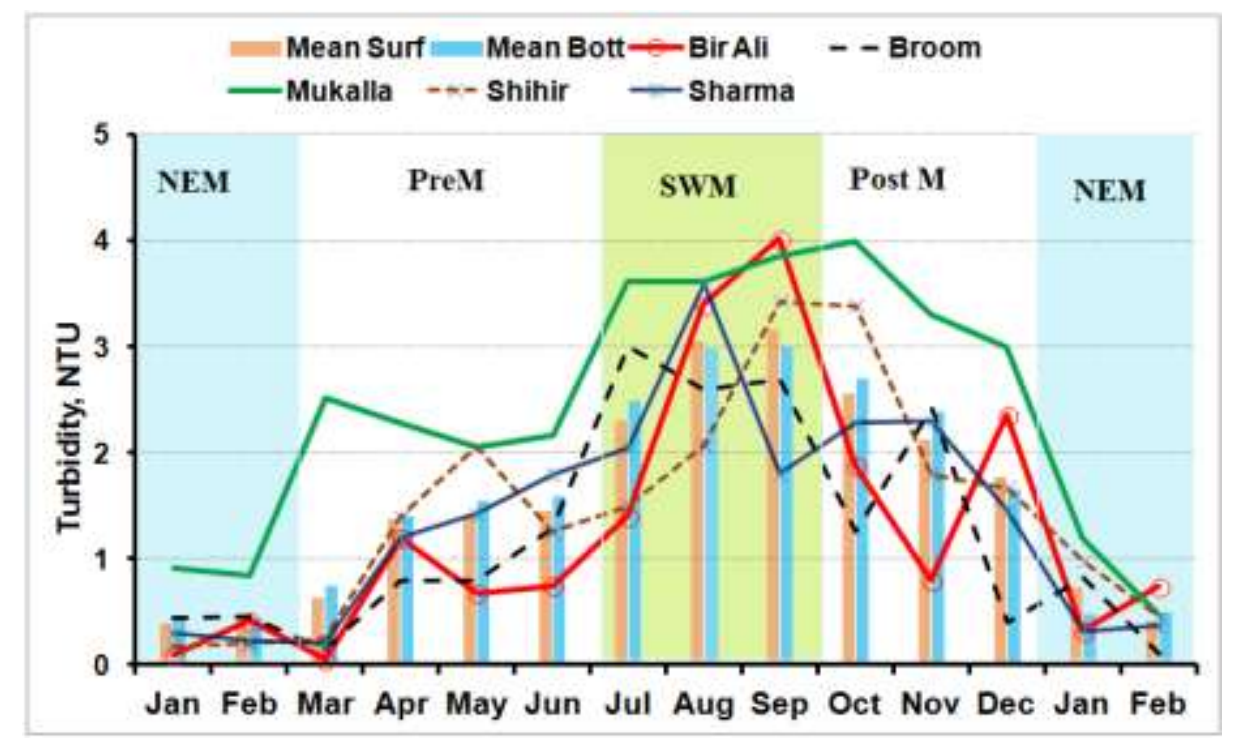

Fig. 9: Yearly Average turbidity (NTU) for Hadhramout coast stations, Jan. 2010 to Feb. 2011. Showing seasonal variation (NEM- Northeast monsoon; PreM- Premonsoo; SWM- Southwest monsoon; PostM- Post monsoon)

At the Interannual scale, a significant increase in turbidity has been observed between May and September, mainly in July and August. The most probable hypothesis to explain this evolution is that the upwelling environment was largely organic in nature.

Among the results, we find a significant convergence of average turbidity- 1.56 and 1.6 NTU respectively for the study period, was observed for the surface and bottom of the Hadhramout coast, although the bottom samples were from above a depth of 80-100 meters. However this convergence can be explained by the high mass of the phytoplankton, the main component of the turbidity value in the mid and surface of the water, while the component of the bottom turbidity can be inorganic deposits and organic nutrients (Ali and Bazar, 2016). This in addition to that this pattern is mainly related to the water masses variations. In the Gulf of Aden there are many mesoscale vortices that remain mostly stationary and will cause a shift and move the water masses in the Gulf during the summer Upwelling (July, August and September). This case rising currents towards the northern coast of the Gulf, mainly the coast of Hadhramout and generate the mixing and vertical homogeneity of the turbidity and its components (Wiggert et al., 2000; Fratantoni et al., 2006). Furthermore, researches show a strong spatial correlation between the mesoscale vortex and the distribution of chlorophyll a (the primary index of phytoplankton biomass) in the Gulf of Aden (Fratantoni et al., 2006).

What distinguishes the coast of Hadhramout is the occurrence of the impact of oceanic currents across the current of Somalia that flow adjacent to the east of African continent. The Current branches ends in the south of the Gulf of Aden 
through the archipelago of Socotra and what it carry of causes of turbidity by its cyclone and anticyclones eddies in the center and the west of the Gulf of Aden. Then its extension to the east of the Gulf, along Hadhramout coast towards the Gulf of Oman, causing the phenomenon of seasonal Upwelling during the Southwestern Monsoon (July - September); this phenomenon, based on the results of this study, appears to be the most frequent cause of the turbidity on the entire coast of Hadhramout, despite the apparent heterogeneity of the turbidity of different stations. However, its indicators generally converge descending in the Northern East Monsoon (January, February and March) and increasingly during the South West Monsoon.

We believe that the relatively low index of the turbidity in the coast of Hadhramout can be due to the dominance of the rocky bottoms in the littoral regions of the studied areas, restricting of beach dumping in the coastal strip, and to the absence of large rivers flowing in the coast, except the seasonal Wadi Hajar in the west and the Masila in east that usually with rare flood, due to the rare rainfall at Hadhramout province. However these figures are considered an important outcomes and indicators for the subsequent studies.

Despite the Turbidity is one of an important environmental factors in the ocean and can gave a grave impact on marine organisms, but it is seemingly not in Hadhramout coast because our results showed relatively low compared with many Indian ocean coasts, like Omani and Arabian gulfs, Pakistani and north Indian coasts (Raghunathan et al., 2003; Melin and Vantrepotte, 2015).

\section{Green pigments (chlorophyll a):}

As a result of this study, Fig. 10 shows the seasonal cycle of chlorophyll $\mathbf{a}$ in the stations of Hadhramout coast; it also highlights the great similarity of these courses in terms of the number of peaks, the clear timing and amount that represented here with two synchronized module. Each of them occurs after the beginning of summer and winter monsoons; minimum was during the periods between monsoons, in the spring and autumn, with marked summer large peak differ from relatively small winter bloom. Also notes that these seasonal cycles that the outcome of monthly tests of chlorophyll give too, to a large extent, a good specific image of the productive areas: of Bir Ali and Broom, the western side of the coast with the existence of premium seasonal productivity of the rest of the stations-Mukalla, Shehir and Sharma.

The minimum concentration value of chlorophyll $\mathbf{a}$ in the surface layer $(10 \mathrm{~m})$, for all areas of the coast within the study period had been observed ( average $0.08 \pm$ $0.07 \mathrm{mg} / \mathrm{m}^{3}$ ) in the period before South West monsoon (April) at the station of Mukalla. The highest $\left(15.2 \pm 0.3 \mathrm{mg} / \mathrm{m}^{3}\right)$ was at the end of South West monsoon (August and September). Significant variations between stations did not observed; except the relatively high index $\left(15.2 \mathrm{mg} / \mathrm{m}^{3}\right.$, at the station of Bir Ali in September), whereas the frequency of gradual reduction towards the east become clear in this month only. There is relative peaks of the index were observed in January, reflecting a winter blooming during the northeast monsoon that clearly highlights in the North Arabian Sea (Prasanna Kumar et al., 2001; Wiggert et al., 2002).

Obvious inter-monsoonal differences distinct from winter monsoon towards summer monsoon. The higher concentration of green pigment mean-more than 4 $\mathrm{mg} / \mathrm{m}^{3}$, prevail during the summer monsoon with highest concentration-more than 6 $\mathrm{mg} / \mathrm{m}^{3}$ had been recorded in all stations. Monthly spatial differences are clear. In general the index of the chlorophyll $\mathbf{a}$ is clearly differs in the summer monsoon from the other two inter- monsoons. 
Thus, a clear phytoplankton blooming during the southwest monsoon is growing during August-September along the east coast of Hadhramout in response to the surface accumulation of induced nutrient by strong upwelling. Here we can note that the change in summer levels of surface concentrations of chlorophyll is factually related to seasonal distributions of nutrients-nitrate and phosphorus with a noticeable movement of silicate peaks to November. Latter pattern is similar to what was revealed by climatologically constructed results in the Gulf of Aden in 1998-2010 and northwestern Arabian Sea in 1998-2006 (Levy et al., 2007).

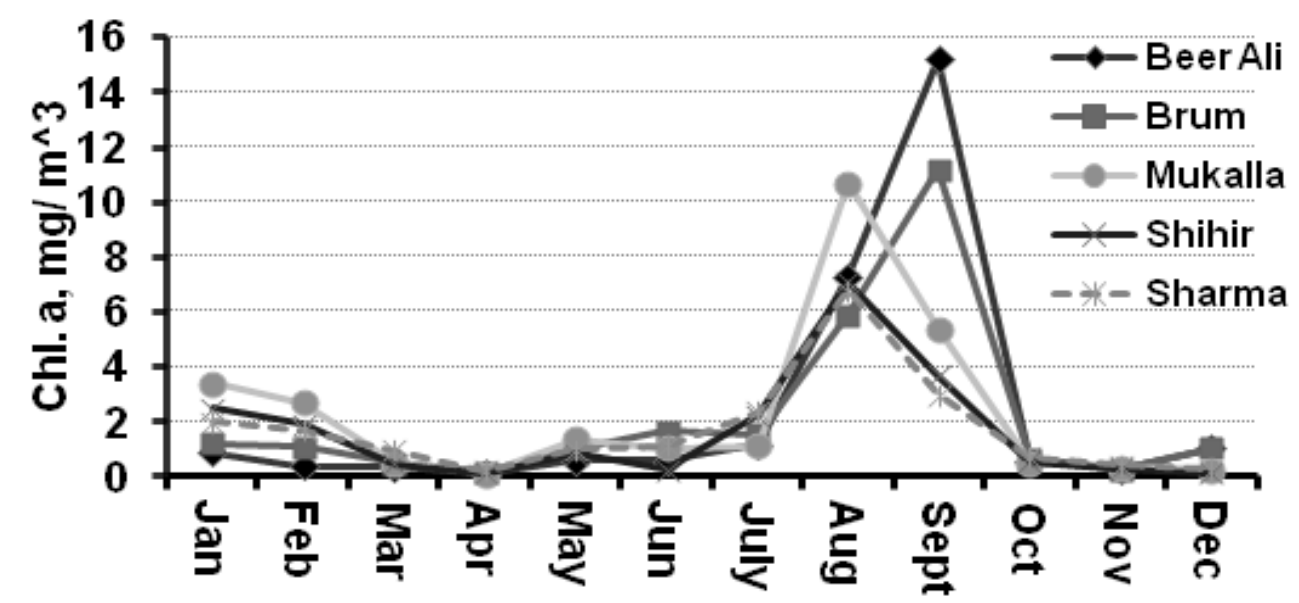

Fig. 10: Chlorophyll a monthly cycle in different Hadhramout coast stations.

Our result shows that there was a good conformity found between the chlorophyll a (the primary of phytoplankton biomass) and the turbidity value, which seems incompatible with the natural concept, this is supported by studies that confirmed that the minimum requirements for light for the growth of phytoplankton is very low (Geider et al., 1987; Wetz et al., 2003).

The important outcome in this aspect of the study is the clarity of the effect of Upwelling and horizontal flow on the frequency of synchronization of the planktonic blooming, whatever the reason, that because of the lifting of nutrients from the bottom, which confirmed here in part, or through the abundance of dissolved organic matter due to the high biological activity here, or even the continuous abundance of plankton in this coast (Ali and Bazar, 2016). Last question remains open to study and comparison to address uncertainty in understanding the planktonic blooming in the Gulf of Aden as a whole and the Hadhramout coast in particular.

The analysis and adoption of the results of abundance and the annual distribution of basic nutrients, which emerged as a result of this study, can be considered a basis for understanding the dynamics of the food chain in the environmental- aquatic system of the coast of Hadhramout. This especially when there is a secured recruitments of nutrients as a basis for the food chain, and secure content of large phytoplankton, which are eaten more easily by zooplankton. Under this conditions the traditional food chain predominate and the hypothesis that the survival of crustaceans and fish larvae is improving when their spread is associated closely with the prey. This hypothesis is now accepted widely and proven in many coastal areas through some studies (Sieburth and Davis, 1982; Fenchel, 1988). Thus, one can exploit this phenomenon or the fact in the 
programming and use of the living food chain for the development of mariculture in the coast of Hadhramout.

Through the analysis of the overall indicators of environmental and biological conditions of the coast, it become clear a perfectibility of water mass to contain fish, crustacean and mollusc communities throughout most months of the year. This, in addition to providing environmental and biological factors for food chain, what gives possibility to judge about the suitability and high feasibility for promotive and commercial mariculture. Environmental circumstances of the coast system devoid of sharp and sudden fluctuations, as study also shows, the conditions flow in a way that avoid the mariculture a high risk of exposure to environmental fluctuations that often occur in many parts of the world (Pérez et al., 2003; IUCN, 2009).

\section{CONCULOSION}

Despite the fact that the study results are preliminary information on the horizontal - vertical structure and variability of seawater conditions characteristics in the region during the year, but it contains some detailed description of the nature and behavior of environmental parameters and their influence on the state of the environment of the Hadhramout coastline. The results pointed out that the coastal waters contains more dissolved oxygen, more nutrients and dissolved organic substances and hence has a higher concentration of plankton, benthos and fishes. It is important that these results can serve as a database for subsequent studies and we have to follow-up the environmental changes in this coast.

\section{REFERENCES}

Agawin, N.; Duarte, C.; and Agusti, S. (2000). Nutrient and temperature control of the contribution of picoplankton to phytoplankton biomass and production. Limnol. Oceanogr., 45: 591-600. doi: 10.4319/lo.2000.45.3.0591

Al-Hashmi, K.A.; Claereboudt, M.; Al-Azri, A.; and Piontovski S. (2010). Seasonal Changes of Chlorophyll a and Environmental Characteristics in the Sea of Oman. The Open Oceanography Journal, 4: 107-114. http://dx.doi.org/10.2174/1874252101004010107

Ali Attaala, M. and Bazar, S.R. (2016). First observations on phytoplankton and chlorophyll ecology in the coast of Hadhramout, Gulf of Aden. International Journal of Fisheries and Aquatic Studies. 4(2):191-202.

Al Saafani, M. A. and Shenoi, S.S.C. (2007). Water masses in the Gulf of Aden. Journal of Oceanography, vol.63 (1):1-14.

Anderson, D.M.and Prell, W.L. (1993). A 300 kyr record of upwelling off Oman during the late Quaternary: evidence of the Asian southwest monsoon. Paleoceanography. 8:193-208.

Baars, M.A.; Schalk, P.H. and Veldhuis, M.J.W. (1998). Seasonal fluctuations in plankton biomass and productivity in the ecosystems of the Somali Current, Gulf of Aden and Southern Red Sea, p 143-174 in: Sherman, K., Okemwa, E.N. and Ntiba, M.J. (eds), Large Marine Ecosystems of the Indian Ocean Assessment, Sustainability and Management. Blackwell Science, Cambridge, U.S.

Bathafari, A.F. (2003). Ecological and biological characteristics of little tuna (Euthynnus affinis) from Aden Gulf (Ph.D Thesis). Astrakhan State Technical University, Astrakhan, Russia. 
Beal, Lisa and Chereskin, Theresa K. (2003). The volume transport of the Somali Current during the 1995 southwest monsoon, Deep-Sea Research Part II: Topical Studies in Oceanography, Volume 50, Issues 12-13: Pages 2077-2089.

Coles, S.L. and Seapy, D,G. (1998). Ultra-violet absorbing compounds and tumorous growths on acroporid corals from Bandar Khayran, Gulf of Oman, Indian Ocean. Coral Reefs 17:195-198

Dubinets, G. A. (1989). Description of the Northern part of Aden Gulf fisheries. AzCherNIRO Bul. 170. Kerch (In Russian)

DeVantier, L.M.; de'ath, G.; Done, T.J. and Turake, E. (1998). Ecological assessment of a complex natural system: a case study from the Great Barrier Reef. Ecological Applications, 8: 480-496.

DeVantier, L.; De'Ath G.; Klaus, R.; Al- Moghrabi, S.; Abdulaziz, M.; Reinicke, G.B. and Cheung, C. (2004). Reef-building corals and coral communities of the Socotra Archipelago, a zoogeographic 'crossroads' in the Arabian Sea. Fauna of Arabia. 20:117-168

Eggs, J.K. and D.L. Aksnes (1992). Silicate as regulating nutrient in phytoplankton competition. Mar. Ecol. Proc. Ser., 83: 281-289.

FAO, (1973). Fishery resources of the Gulf of Aden and some adjacent areas. A report prepared for the Fishery Development In the Gulf of Aden Project. Based on the work of A. Druzhlnln, Fishery Biologist. Rome, FAO. FI: SF/DP 9/12 PDY 64/501/7:299 p.

Fenchel, T. (1988). Marine plankton food chains. Annu. Rev. Ecol. Syst. 19: 19-38

Fratantoni, D.M.; A.S. Bower and Peters H. (2006). Somali current rings eastern Gulf of Aden. J. Geophysics Research, 111: C09039, doi:10.1029/2005JC003338.

Geider, R. J. (1987). Light and temperature dependence of the carbon to chlorophyll ratlo In microalgae and cyanobacteria: implications for physiology and growth of phytoplankton. New Phytol, 106: 1-34

IFAD, (2010). Fisheries investment project, Republic of Yemen. Project final design report, 92pp (Main report and Annexes). Available:http://www.ifad.org/operations/pr ojects/design/ 101/yemen.pdf October 2016].

IUCN, (2009). Guide for the Sustainable Development of Mediterranean Aquaculture 2. Aquaculture site selection and site management, IUCN, Gland, Switzerland and Malaga, Spain. VIII + 303 pages.

Kawasaki, T.; S. Tanaka; Y. Toba and A. Taniguchi (eds.) (1991). Long-term Variability of Pelagic Fish population and their environment. Tokyo, Japan: Pergamon Press, pp. 402.

Kemp, J. M. and Benzoni, F. (2000). A preliminary study of the coral communities in the northern Gulf of Aden. Fauna Arabia, 18:67-86

Khimitsa, V.A. (1970). Some seasonal peculiarity dynamic of hydrochemical features of Aden gulf and Arabian Sea. Chemical Resources of Seas and Oceans, Nayka (Science) Press, Moscow, pp. 93-120 [Russian]

Krey, J. and Babenerd B. (1976). Phytoplankton Production Atlas of the International Indian Ocean Expedition. Intergovernmental Oceanographic Commission, Paris, 70pp.

Levy, M.; Shankar, D.; Andre J.M.; Shenoi S.S.C.; Durand, F. and Montegut, C.D.B. (2007). Basin-wide seasonal evolution of the Indian Ocean's phytoplankton blooms. J Geophys Res. 112: C12014

Mann, K. and Lazier, J. (2006). Dynamics of marine ecosystems: biological and physical interactions in the oceans. Blackwell Publishing. 394 pp. 
Madhupratap, M.; Nair, V.R.; Nair, S.R.S.; Achuthankutty, C.T. (1981). Zooplankton abundance of the Andaman Sea. Indian Journal of Marine Sciences, 10: 258261.

Nair, V.R. (1980). Organic carbon content of tropical zooplankton. Indian Journal of Marine Science, 9(2):114-116.

Nixon, S. W. (1988). Physical energy inputs and the comparative ecology of lake and marine ecosystems. Limnol. Oceanogr., 33: 1005-1025.

Omstedt, A.; M. Edman; L.G. Anderson and H. Laudon. (2010). Factors influencing the acid-base $(\mathrm{pH})$ balance in the Baltic Sea: a sensitivity analysis. Tellus, 62: pp. 280-295

Pearson, P.N. and Palmer, M.R. (2000). Atmospheric carbon dioxide concentrations over the past 60 million years. Nature, 406: 695-699.

Pérez, O.M.; L.G. Ross; T.C. Telfer and L.M. del Campo Barquin. (2003). Water quality requirements for marine fish cage site selection in Tenerife (Canary Islands). Aquaculture, 224:51-68.

Piontkovski, S.A. and Claereboudt, M.R. (2012). Interannual changes of the Arabian Sea productivity. Mar Biol Res, 8:189- 194.

Prassana Kumar, S.; Ramaiah, N.; Gauns, M.; Sarma, V. V. S. S., Muraleedharan, P. M.; RaghuKumar, S.; Dileep Kumar, M. and Madhupratap, M. (2001). Physical forcing of biological productivity in the Northern Arabian Sea during the Northeast Monsoon, Deep- Sea Res. Pt. II., 48: 1115-1126, https://doi.org/10.1016/S0967- 0645(00)00133-8.

Raghunathan, A.U.; Perez-Correa, J.R. and Bieger, L.T. (2003). Data reconciliation and parameter estimation in flux-balance analysis. Biotechnol Bioeng, 84(6):700-9

Sarma, V. V. S. S.; Krishna, M. S.; Paul, Y. S. and Murty, V. S. N. (2015). Observed changes in ocean acidity and carbon dioxide exchange in the coastal Bay of Bengal - a link to air pollution. Tellus B: Chemical and Physical Meteorology, 67(1). https://doi.org/10.3402/tellusb.v67.24638

Satpathy, K.K.; Sahu G.; Mohanty, A.K.; Prasad, M.V.R. and Panigrahy, R.C. (2009). Phytoplankton community structure and its variability during southwest to northeast monsoon transition in the coastal waters of Kalpakkam, east coast of India. Int J Ocean Oceanography, 3:43-74

Shi, X.Y.; Y. Wang, and Xu X.D. (2008). Effect of mesoscale topography over the Tibetan Plateau on summer precipitation in China: A regional model study. Geophys. Res. Lett., 35: L19707.

Sieburth, J. McN. and Davis, P.G. (1982). The role of heterotrophic nanoplankton in the grazing and nurturing of the planktonic bacteria in the Sargasso and Caribbean Seas. Ann. Inst. Oceanogr. Paris, 58, 285-296.

Sigman, D. M. and Hain, M. P. (2012). The Biological Productivity of the Ocean: Section 2. Nature Education Knowledge, 3(10):20

Skalar analytical, B.V. (1996). Operating manual. Skalar analytical B.V. Breda, The Netherlands

Strickland, J. and Parsons, T., (1972). A practical handbook of sea water analysis. Fisheries research board of Canada, Ottawa, Canada. 293p.

Turner, A. and Millward, G.E. (2002). Suspended Particles: Their Role in Estuarine Biogeochemical Cycles. Estuarine, Coastal and Shelf Science, 55: 857-883. http://dx.doi.org/10.1006/ecss.2002.1033

Wyrtki, K. (1973). Physical oceanography of the Indian Ocean: The Biology of the Indian Ocean, B. Zeitzschel, Ed., Springer-Verlag, Berlin, 18-36. 
Wang, Z. H.; Cui, F. Y.; An, Q.; Chen, M. M.; Wu, B. F. and Guan, X. L. (2004). Study on influence of $\mathrm{pH}$ on the advance of eutrophication in reservoir. Water and Wastewater Engineering, 30 (5) : 37-41.

Wang, M. and W. Shi (2008). Satellite observed blue-green algae blooms in China's Lake Taihu, EOS, Transaction, AGU, 89 (22): 201-202, doi:10.1029/2008EO220001.

Wetz, M. S.; Wheeler, P. A. and Letelier, R. M. (2003). 171 Light-Induced Growth of Winter Phytoplankton Collected from the Benthic Boundary Layer in Coastal Oregon Waters. J. Phycol. 39: 59-59, https://doi.org/10.1111/j.00223646.2003.03906002_171.x.

Wiebinga, Cas J. ; Veldhuis, Marcel J.W. and Baar, Hein J.W. de. (1997). Abundance and productivity of bacterioplankton in relation to seasonal upwelling in the northwest Indian Ocean. In: Deep Sea Research Part I. Oceanographic Research Papers. Vol. 44, No. 3: 451-476

Wiggert, J. D.; Jones, B.H.; Dickey, T.D.; Brink, K.H.; Weller, R.A.; Marra, J. and Cadispoti, L.A. (2000). The northeast monsoon's impact on mixing, phytoplankton biomass and nutrient cycling in the Arabian Sea. Deep-Sea Res., 47:1353-1386

Wiggert, J.D.; Murtugudde, R.G. and McClain, C.R. (2002). Processes controlling interannual variations in winter- time (Northeast Monsoon) primary productivity in the central Arabian Sea. Deep-Sea Research II, 49: 2319-2343. 